CÓRDOBA-FIGUEROA, ME; CRIOLLO-ESCOBAR, H; INSUASTY-CÓRDOBA, S; MATEUS-RODRÍGUEZ, JF. 2021. Differential growth and yield responses of local potato cultivars from basic seed tubers. Horticultura Brasileira 39: 272-278. DOI: http://dx.doi.org/10.1590/s0102-0536-20210305

\title{
Differential growth and yield responses of local potato cultivars from basic seed tubers
}

\author{
Mónica Eliana Córdoba-Figueroa ${ }^{1} \mathbb{D}$; Hernando Criollo-Escobar ${ }^{2} \mathbb{D}+\frac{.}{\text {; }}$ Sandra Insuasty-Córdoba ${ }^{1} \mathbb{D}$; Julián \\ Fernando Mateus-Rodríguez ${ }^{3 \mathbb{1}}$
}

${ }^{1}$ Corporación Colombiana de Investigación Agropecuaria (AGROSAVIA). CI Obonuco, Nariño, Colombia; monicacordoba1217@hotmail. com; sinsuasty@agrosavia.co; ${ }^{2}$ Universidad de Nariño (UDENAR), Campus Las Acacias, Nariño, Colombia; hcriolloescobar@gmail.com; ${ }^{3}$ Corporación Colombiana de Investigación Agropecuaria (AGROSAVIA), CI Palmira, Valle del Cauca, Colombia; jmateus@agrosavia.co

\begin{abstract}
Potato quality of seed tubers is a determinant factor that allows obtaining high yields, and its use must be a priority for a country or a producing region. Lack of information about how local cultivars perform differentially according to the environment has been identified in order to support potential seeds production programs. The research was carried out in 2018 at the Obonuco Research Center of Corporación Colombiana de Investigación Agropecuaria (AGROSAVIA), with the aim of analyzing the growth and yield of basic tuber seeds of five potato (Solanum tuberosum spp. andigena) cultivars. 1,080 seed tubers from each cultivar (treatments) were planted in a completely randomized block design and three replications. Mean comparison Tukey-Kramer $(p \leq 0.05)$ test was performed for the yield analysis. From emergency to final harvest, destructive sampling was carried out every fifteen days in order to calculate dry matter and leaf area and establish growth models based on the accumulated degree-days (DD). The yield and proportion of seed tubers per plant were determined according to local resolution for seed certification in Colombia. Growth variables fitted better with the Hoerl, Gaussian, and third-degree polynomial models. The leaf area index of the potato cultivars reached the maximum value at 876 $\mathrm{DD}$, with values ranging from 2.91 to $6.11 \mathrm{DD}$. The highest yield per plant was obtained by the Ica Única cultivar $\left(2.73 \mathrm{~kg} \mathrm{plant}^{-1}\right)$. However, this cultivar showed the lowest percentage of seed tubers, with $50.59 \%$ compared to the others, which ranged between 80.82 and $87.40 \%$. Differential potato growth responses through models based on the DD would explain the differences in final yield and seeds tuber production.
\end{abstract}

Keywords: Solanum tuberosum, growth analysis, seed tubers.

\section{RESUMO}

Crescimento diferencial e respostas de produção de cultivares locais de batata a partir de tubérculos-semente básicos

A qualidade dos tubérculos-semente da batata é um fator determinante para a obtenção de elevados rendimentos, devendo a sua utilização ser prioritária para um país ou região produtora. A falta de informações sobre como as cultivares locais atuam de forma diferenciada de acordo com o ambiente, foi identificada, a fim de apoiar programas de produção de sementes em potencial. A pesquisa foi realizada em 2018 no Centro de Pesquisas Obonuco da Corporación Colombiana de Investigación Agropecuaria (AGROSAVIA), com o objetivo de analisar o crescimento e a produção de tubérculos-semente de cinco cultivares de batata (Solanum tuberosum spp. andigena). 1.080 tubérculos-semente de cada cultivar (tratamentos) foram plantados em delineamento de blocos ao acaso e três repetições. O teste de comparação de médias de Tukey-Kramer $(\mathrm{p} \leq 0,05)$ foi realizado para a análise do rendimento. $\mathrm{Da}$ emergência até a colheita final, foram realizadas coletas destrutivas quinzenais para cálculo da matéria seca e área foliar e estabelecimento de modelos de crescimento com base nos graus-dias (DD) acumulados. O rendimento e a proporção de tubérculos-semente por planta foram determinados de acordo com a resolução local para certificação de sementes na Colômbia. As variáveis de crescimento se ajustaram melhor aos modelos polinomiais de Hoerl, Gaussiano e de terceiro grau. $\mathrm{O}$ índice de área foliar das cultivares de batata atingiu o valor máximo em $876 \mathrm{DD}$, com valores variando de 2,91 a 6,11 DD. A maior produtividade por planta foi obtida pela cultivar Ica Única $\left(2,73 \mathrm{~kg} \mathrm{planta}^{-1}\right)$. No entanto, essa cultivar apresentou a menor porcentagem de tubérculos-semente, com 50,59\% em relação às demais, que variaram entre 80,82 e $87,40 \%$. As respostas diferenciais de crescimento da batata por meio de modelos baseados no DD explicariam as diferenças no rendimento final e na produção de tubérculo-sementes.

Palavras-chave: Solanum tuberosum, análise de crescimento, tubérculos-semente.

Received on July 16, 2020; accepted on June 16, 2021

$\mathrm{P}$ otato (Solanum tuberosum spp. andigena, Solanaceae) origin and domestication took place in South America (Asfaw, 2016). Approximately
19.34 million hectares of potato are cultivated worldwide in more than 158 countries, with an estimated annual production of 364 million tons (Romero et al., 2017). Production is concentrated in mountain regions, with an optimal altitude for commercial varieties ranging between 2,500 and 3,000 $\mathrm{m}$ above the 
sea level (Rodríguez, 2010).

Around 110,000 families cultivate potato which leads to more than 300,000 farming jobs in Colombia. The total production is around 2-3 million $t$ year ${ }^{-1}$ and average yield of $21 \mathrm{t} \mathrm{ha}^{-1}$ (FEDEPAPA, 2017). The availability of high-quality tuber seeds is the main constraint in the potato crop system and most of the farmers recycle the seeds or obtain it from informal systems (MADR, 2014; Buckseth, 2016). Consequently, in Colombia, no more than $3 \%$ of the total potato area is used to produce this important component (Ariza, 2018).

Despite the high variability of potato genotypes in the country, the production is based in no more than 12 commercial varieties. The industrial variety Diacol Capiro occupied $23 \%$ of the potato production in 2018. New alternatives such as Pastusa Superior with high yield and culinary quality have increased the cultivation area (around 23\%) due to the rapid adoption among farmers and local markets. Additionally, Ica Unica variety with a few local varieties occupy the other $50 \%$ of the total area (MADR, 2019).

The crop is propagated through underground stems or tubers; therefore, the tuber seeds are important because these largely determine the yield of the commercial crop, and are the vehicle through which improved and native cultivars are disseminated and maintained. Seed tubers also constitute a strategic input to preserve the food sovereignty and genetic diversity of a country (Piedra, 2016). In large-scale production systems, the use of high genetic and physiological quality seed is closely related to ensuring high productivity (Peske et al., 2010). For Awati et al. (2018), seed tubers are a key factor for a competitive potato cropping production, representing about $40 \%$ of the total crop production costs.

The morphology and physiology of potato plants is affected by abiotic factors such as latitude, altitude, temperature, day length, light intensity, soil water content and fertility. The genotype performance can be modified due to its ability to alter the phenotype according to environmental changes
(Rodríguez, 2010). The crop requires an adequate soil, water, carbon dioxide $\left(\mathrm{CO}_{2}\right)$ supply, as well as adequate radiation for the photosynthetic process [Photosynthetically Active Radiation (PAR)] when focusing on achieving good total productivity throughout the production cycle. Rodríguez (2010) stated that at least $90 \%$ of the dry biomass of a potato plant is obtained due to the photosynthetic process that transforms light energy into chemical energy, and under which atmospheric $\mathrm{CO}_{2}$ is fixed and converted to carbohydrates; these are subsequently distributed throughout the plant towards the growth and storage organs.

Despite the socio-economic importance of the crop for the potato regions of the country, there are not enough reports focused on the physiological responses of cultivars of local interest, with relevance for small and medium producers. This type of information seeks to establish basic knowledge for the corresponding agronomic management adjustments to focus on achieving quality and high yields in early seed production stages. Accordingly, the aim of this study was to analyze the basic seed tubers growth and yield of five potato cultivars.

\section{MATERIAL AND METHODS}

The experiment was carried out during a basic category seed production from May to November 2018 in the Obonuco Research Center of Corporación Colombiana de Investigación Agropecuaria - AGROSAVIA, (01 ${ }^{\circ} 1^{\prime 2} 28^{\prime \prime} \mathrm{N}, 7^{\circ} 19^{\prime} 09^{\prime \prime} \mathrm{W}, 2,957 \mathrm{~m}$ altitude) in the municipality of Pasto, department of Nariño (Colombia). During the experimental period, there was a minimum and maximum temperature of $5.9^{\circ} \mathrm{C}$ and $21.1^{\circ} \mathrm{C}$ respectively, $82 \%$ relative humidity, $662 \mathrm{~mm}$ rain cumulative and $133 \mathrm{wm}^{-2}$ solar radiation. The soil was classified as Typic Haplustults, being characterized: $\mathrm{pH}=5.7$; Soil organic matter $(\mathrm{SOM})=$ $16.85{\mathrm{~g} 100 \mathrm{~g}^{-1}, \mathrm{~K}=0.5 \mathrm{cmol} \mathrm{kg}}^{-1} ; \mathrm{P}$, $\mathrm{B}, \mathrm{Zn}, \mathrm{Mn}, \mathrm{Cu}, \mathrm{Fe}$ and $\mathrm{S}=18.73 ; 0.19$; $1.39 ; 5 ; 1.16 ; 137.11$ and $1.16 \mathrm{mg} \mathrm{kg}^{-1}$, respectively and $\mathrm{Ca}=73 \%, \mathrm{Mg}=17 \%$, cation exchange capacity $(\mathrm{CEC})=6.69$ $\mathrm{cmol} \mathrm{kg}{ }^{-1}$. Conventional soil preparation was made using disc harrow and chisel plough. Basic category seed tubers of Ica Única, Pastusa Superior, Parda Pastusa, Diacol Capiro, and Pastusa Suprema cultivars with 31 to $90 \mathrm{~mm}$ diameter and $3 \mathrm{~mm}$ sprout length were planted in a completely randomized block design with three blocks of 864 $\mathrm{m}^{2}$. The cultivars were distributed in plots of $129.6 \mathrm{~m}^{2}$ with a population of 1,080 tubers per cultivar; the rows were separated by $1.20 \mathrm{~m}$ and $0.30 \mathrm{~m}$ between plants. A Davis Vantage Pro-2 portable station was used to record climatic variables: maximum and minimum temperatures $\left({ }^{\circ} \mathrm{C}\right)$, relative humidity $(\%)$, total accumulated rainfall, and solar radiation $\left(\mathrm{wm}^{-2}\right)$. Based on the soil analysis, fertilization was performed in two applications. First application 40 days after planting: $30 \mathrm{~g} / \mathrm{plant}$ of a mixture of $150 \mathrm{~kg}\left(12 \% \mathrm{~N}, 24 \% \mathrm{P}_{2} \mathrm{O}_{5}\right.$, $\left.12 \% \mathrm{~K}_{2} \mathrm{O}\right) ; 25 \mathrm{~kg}(21 \% \mathrm{~N}, 11 \% \mathrm{CaO}$, $7.5 \% \mathrm{MgO})$ and $25 \mathrm{~kg}(8 \% \mathrm{~N}, 5 \%$ $\left.\mathrm{P}_{2} \mathrm{O}_{5}, 6 \% \mathrm{MgO}\right)$. Second application 68 days after planting: $20 \mathrm{~g}(10 \% \mathrm{~N}, 20 \%$ $\mathrm{P}_{2} \mathrm{O}_{5}, 20 \% \mathrm{~K}_{2} \mathrm{O}$ ) per plant. A preventive integrated pest and disease management was made under guidelines established by the resolution 003168 of 2015 for potato seed production in Colombia (ICA, 2015).

Accumulated degree-days (DD) $=$ $(\mathrm{Tmax}+\mathrm{Tmin}) / 2-\mathrm{Tb}$, where $T$ min is the minimum daily temperature, $\operatorname{Tmax}$ is the maximum daily temperature, and $T b$ is the base temperature or lower threshold for the beginning of the potato growth period, i.e., $6^{\circ} \mathrm{C}$, established by Cao \& Tibbitts (1995), was calculated according to Miller et al. (2001). For the purpose of the research, the mean of DD for the experimental period has been calculated in 6.7.

20 days after the seed tubers emergence and a periodicity of 15 days until the end of the crop cycle, three plants per cultivar were randomly extracted from each block to establish the parameters under the study.

Plant height $(\mathrm{PH})$ measured in centimeters, was obtained from the base of the plant to the shoot apex of the longer stem using a measuring tape. Leaf area (LA) of 10 plant tissue discs were extracted per plant with a punch 
(with a known area of $153.94 \mathrm{~mm}^{2}$ ); subsequently, they were dried in an oven at a constant temperature of $70^{\circ} \mathrm{C}$ together with the rest of the leaves. The LA was estimated from the equation LA $=($ dry area of the leaves $\mathrm{X}$ area of the discs)/dry matter of the discs (Cardona et al., 2009). Leaf area index (LAI) was defined as the leaf surface area per unit soil surface area (LAI $=\mathrm{LA} / \mathrm{SA})$ where LA is the leaf area $\left(\mathrm{dm}^{2}\right)$, and SA is the soil area $\left(\mathrm{dm}^{2}\right)$ (Campostrini \& Yamanisi, 2001).

The net assimilation intensity (NAI) was estimated using the equation published by Hunt et al. (2002) and modified for this study. NAI $\left(\mathrm{g} \mathrm{dm}^{-2}\right.$ $\left.\mathrm{DD}^{-1}\right)=\left(\mathrm{W}_{2}-\mathrm{W}_{1}\right) /\left(\mathrm{DD}_{2}-\mathrm{DD}_{1}\right) \mathrm{X}\left(\operatorname{lnLA}_{2}-\right.$ $\left.\ln \mathrm{LA}_{1}\right) /\left(\mathrm{LA}_{2}-\mathrm{LA}_{1}\right)$, where $\ln$ is the natural logarithm, and $\mathrm{LA}_{1}$ and $\mathrm{LA}_{2}$ are the leaf areas in $\mathrm{dm}^{2}$ at the beginning and end of the degree-days interval, respectively. Further, $\mathrm{W}_{1}$ and $\mathrm{W}_{2}$ are the dry weight values in $g$ at the beginning and end of the degree-days interval, respectively, and $\mathrm{DD}_{1}$ and $\mathrm{DD}_{2}$ are the degree-days at the beginning and end of the day, respectively.

Crop growth index (CGI) was calculated using the equation of Fageria et al. (2006) and modified for this study as follows. CGI $\left(\mathrm{g} \mathrm{dm}^{-2} \mathrm{DD}^{-1}\right)=\left(\mathrm{W}_{2}-\mathrm{W}_{1} /\right.$ $\left.\mathrm{DD}_{2}-\mathrm{DD}_{1}\right) \mathrm{X} 1 / \mathrm{SA}$, where $\mathrm{W}_{1}$ and $\mathrm{W}_{2}$ are the initial and final weights in $g$ in the period evaluated, respectively, $\mathrm{DD}_{1}$ and $\mathrm{DD}_{2}$ are the initial and final degree-days, respectively, and AS is the soil area.

For dry matter (DM), the different plant organs were separated, packed in paper bags with their respective label and placed at a constant temperature of $70^{\circ} \mathrm{C}$ for 72 hours (Silva et al., 2018) using a Memmert brand UN 750 plus oven. Subsequently, the samples were weighed on a Vibra analytical balance $(\mathrm{d}= \pm 0.001 \mathrm{~g})$. The average weight of the different organs obtained was transformed into a percentage value. Finally, the yield per crop (YC) was calculated from the weight of the tubers produced per plant $\left(\mathrm{kg}\right.$ plant $\left.{ }^{-1}\right)$. Seed tubers production was established as a percentage of tubers between 31-90 mm according to the guidelines established by the resolution 003168 of 2015 (ICA).

The growth of the potato cultivars assessed was established through a functional analysis, considering the accumulated degree-days as an independent variable; the Curve Expert software version 1.4 was used. The variables yield and percentage of seed tubers were subjected to analysis of variance and the mean comparison test of Tukey-Kramer $(p \leq 0.05)$, using the SAS statistical package version 9.4 (SAS Institute Inc., Cary., NC, USA).

\section{RESULTS AND DISCUSSION}

Plant height $(\mathrm{PH})$ for the cultivars showed a slow elongation until 367 DD, and then turning logarithmic until 712 DD. Subsequently, it showed a slow response until reaching its maximum value (Figure 1). Parda
Pastusa outperformed the rest of the cultivars. Rodríguez et al. (2016) also observed this response and highlighted the important plasticity capacity in morphological features that allows this variety to use light efficiently. In addition, the results are similar to those presented by the same authors under different conditions, where the Diacol Capiro cultivar showed lower plant height values.

Leaf area index (LAI) throughout the thermal accumulation period fitted best to the Hoerl model (Figure 2) in the cultivars Diacol Capiro and Pastusa Superior, and to the Gaussian model in Parda Pastusa and Pastusa Suprema; further, it fitted to the third-degree polynomial type in Ica Única. LAI values of $2.87,2.51$, and 1.6 for the

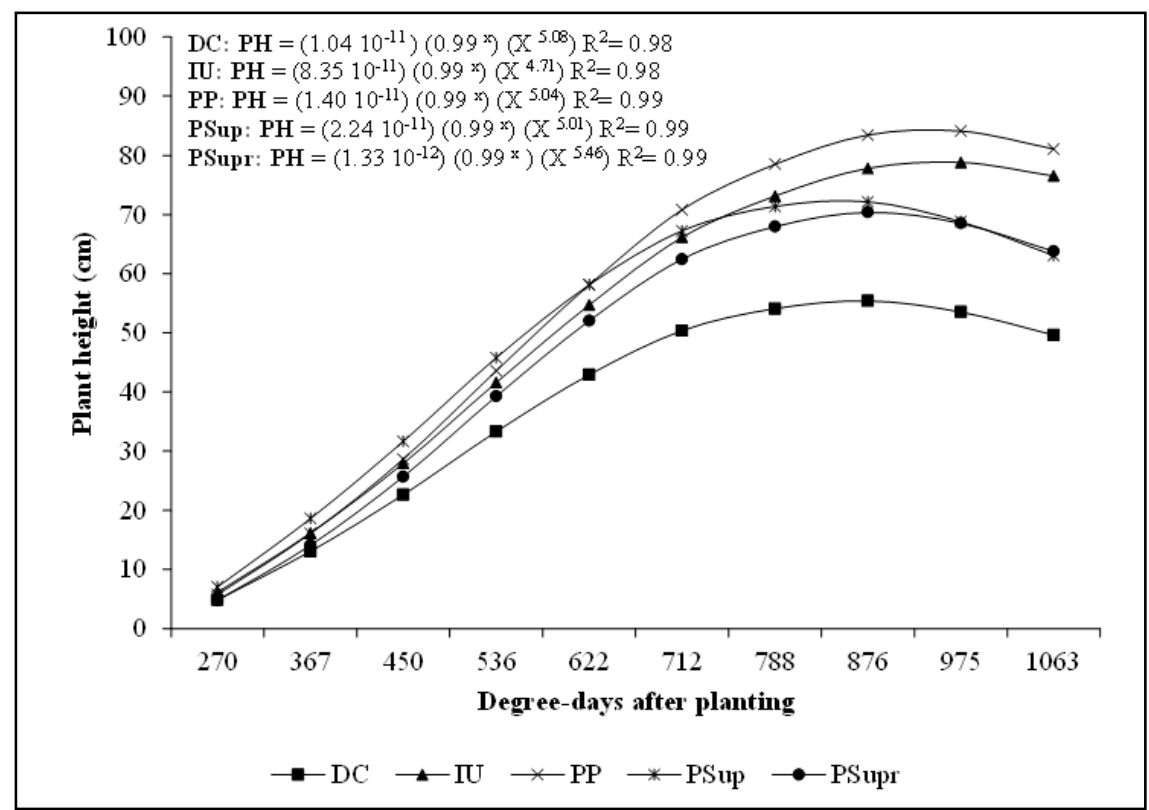

Figure 1. Progress plant height (PH) curves through accumulated degree-days (DD) of Diacol Capiro (DC), Ica Única (IU), Parda Pastusa (PP), Pastusa Superior (PSup), and Pastusa Suprema (PSupr). Colombia, AGROSAVIA, 2018.

Table 1. Yield per plant and yield of seed tubers of potato cultivars. Colombia, AGROSAVIA, 2018.

\begin{tabular}{lcc}
\hline Cultivar & Yield in tuber $\left(\mathbf{k g ~ p l a n t}^{-\mathbf{1}}\right)$ & Yield of seed tubers $^{\mathbf{1}}(\mathbf{\%})$ \\
\hline Diacol Capiro & $1.88 * \mathrm{~b}$ & $87.40 \mathrm{a}$ \\
Pastusa Superior & $2.09 \mathrm{~b}$ & $84.32 \mathrm{a}$ \\
Parda Pastusa & $1.93 \mathrm{~b}$ & $81.83 \mathrm{a}$ \\
Pastusa Suprema & $2.18 \mathrm{~b}$ & $80.82 \mathrm{a}$ \\
Ica Única & $2.73 \mathrm{a}$ & $50.59 \mathrm{~b}$ \\
\hline CV (\%) & 7.20 & 3.75 \\
\hline
\end{tabular}

*Means with the same letter are not significantly different from each other by Tukey-Kramer test $(\mathrm{p} \leq 0.05)$. ${ }^{1}$ Tuber seeds diameter between $31-90 \mathrm{~mm}$. 
cultivars Esmeralda, Betina, and Diacol Capiro, respectively, were reported by Santos et al. (2010) in conditions of Cundinamarca department. The difference in the LAI values between the cultivars studied could be related to the plant architecture and the specific development pattern of each cultivar interacting with the local environmental conditions (De la Casa et al., 2007; Jerez
\& Martín, 2012). Working with four potato varieties, Howlader \& Hoque (2018) observed differences in response to growth, which corresponded to the genetic factor and its corresponding interaction with the environment. The LAI response of Pastusa Suprema (4.77), Pastusa Superior (4.70), Ica Única (4.72), and Diacol Capiro (2.91) are consistent with the values published

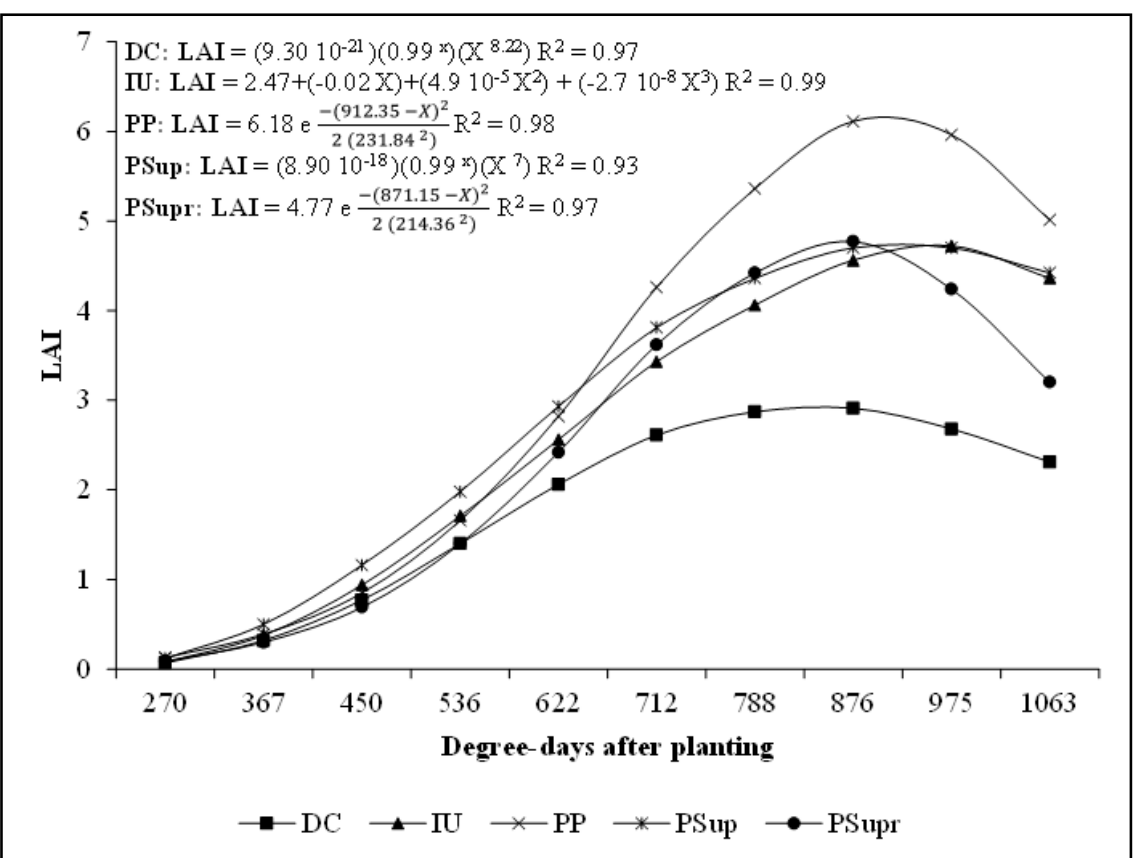

Figure 2. Progress leaf area index (LAI) curves through accumulated degree-days (DD) of Diacol Capiro (DC), Ica Única (IU), Parda Pastusa (PP), Pastusa Superior (PSup), and Pastusa Suprema (PSupr). Colombia, AGROSAVIA, 2018.

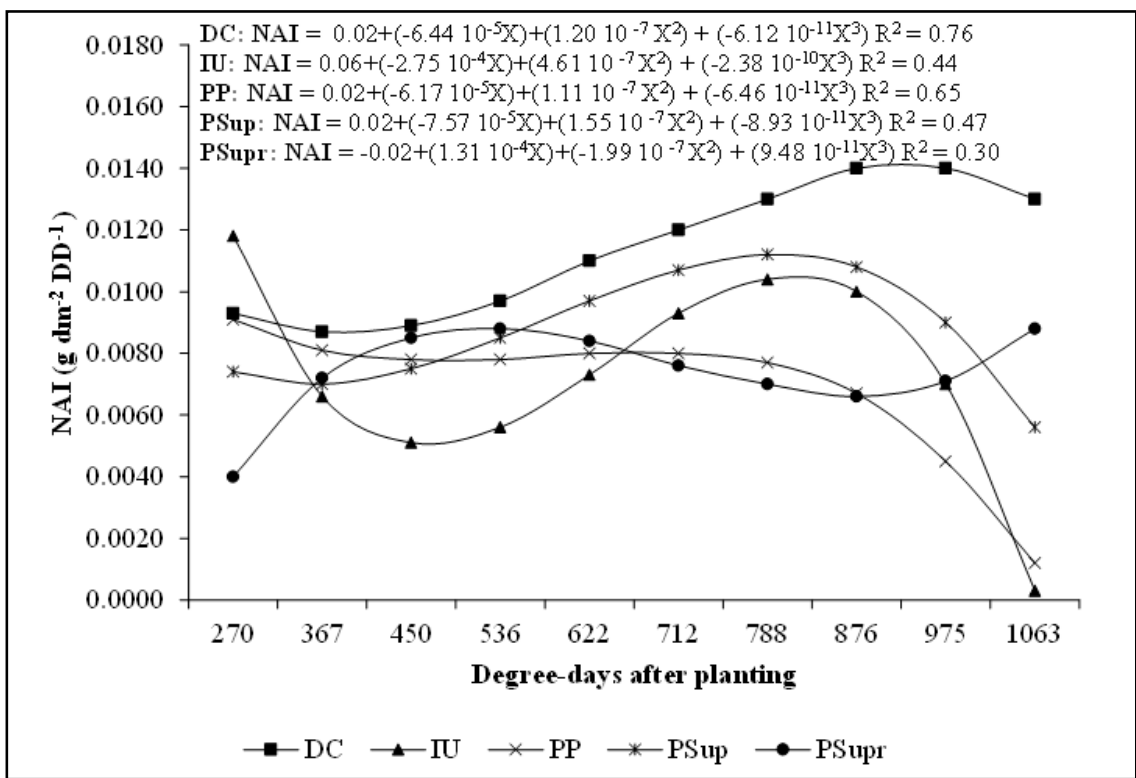

Figure 3. Progress net assimilation index (NAI) curves through accumulated degree-days (DD) of Diacol Capiro (DC), Ica Única (IU), Parda Pastusa (PP), Pastusa Superior (PSup), and Pastusa Suprema (PSupr). Colombia, AGROSAVIA, 2018. by De la Casa et al. (2011) when evaluating the effect of plant density. The authors reported that in the middle of the productive cycle, the LAI was higher in high densities (4.47), intermediate in commercial densities (4.19), and low in lower planting densities (3.54).

The leaf area index for Ica Única, Pastusa Suprema, and Pastusa Superior was similar to what Romero et al. (2017) reported, who observed for cultivars, such as Diacol Capiro and Perla Negra, LAI values of 4.7 and 4.2 , respectively. An increase in the LAI allows plants to make better use of solar energy, which is essential in the photosynthesis process; this in turns allows a better biomass production and an increase in the size of the tubers, which finally ensures an adequate yield (De la Casa et al., 2007).

The net assimilation index (NAI) presented a differential response among cultivars, following a third-degree polynomial type response (Figure 3). The Pastusa Suprema cultivar at the beginning showed a low NAI compared to the other cultivars, with wide variability in its response, associated most seemingly with higher requirements due to senescence and leaf loss during the different phenological cycle stages. This type of fluctuations along the thermal accumulation seems to be susceptible to different environmental variations (Jerez et al., 2016). The highest NAI records were found in the cultivars Diacol Capiro, Ica Única, and Pastusa Superior, which showed the highest dry matter production per leaf area unit and per accumulated degreedays. This indicates a higher efficiency in the photosynthesis process, resulting in higher yields, as expressed by Santos et al. (2010). Parda Pastusa and Diacol Capiro presented the highest NAI values at 788 and 876 DD respectively with a subsequent decreased due to a reduction in stem and leaves dry biomass.

Crop growth index (CGI) was similar across the cultivars evaluated (Figure 4). An increase was observed until reaching the highest value recorded at 975 DD for Pastusa Suprema with $0.0321 \mathrm{~g} \mathrm{dm}^{-2} \mathrm{DD}^{-1}$. On the other hand, the highest values for the rest of the cultivars were recorded at 1,063 DD. Thomas et al. (2016) suggested that the maximum value reached corresponds 
to the highest productive efficiency per soil surface unit and per cumulative degree-days. For the Diacol Capiro and Parda Pastusa cultivars, a fitted adjusted to the third-degree polynomial model was found, while for the Ica Única and Pastusa Superior cultivars, the quadratic model explained much better the response. Finally, the Pastusa Suprema showed a good fit for the Hoerl model. These findings are in accordance with Howlader \& Hoque (2018) using Asterix, Cardinal, and Diamant varieties.

Total dry matter per plant (TDMP) included roots, tubers, stolons, stems, leaves, flowers, and fruits over the accumulated degree-days (Figure 5). In the first stage of the cycle, the cultivars showed a low increase in dry matter (1.11-5.53 $\left.\mathrm{g} \mathrm{plant}^{-1}\right)$. Subsequently, an increase was evidenced through the accumulation of degree-days, reaching total biomass between 479.61 and $582.37 \mathrm{~g}$ at $1,063 \mathrm{DD}$. This response variable was adjusted using the Hoerl model for Diacol Capiro and the Gaussian model for the other cultivars. Foliage efficiency in terms of solar radiation interception is translated into an appropriate accumulation of dry matter and distribution by the plant. The results are similar to those reported by Aguilar et al. (2006), who suggested that prior to the tuberization event, the production of photoassimilates is used for the initial development of leaves, stems, and roots. Once the tuberization process has started, the trend changes. The increase in the $\mathrm{DM}$ of the tubers is due to the greater distribution of assimilates from the source organs (leaves) and the ability to attract these elaborated elements to the dumping organs (tubers) (Santos et al., 2010). There are regulatory centers involved in the control of the distribution of photoassimilates through which enzymatic activities are carried out, and the flow of metabolic pathways can change (Warren, 1981).

Related to the yield per plant, the analysis of variance showed highly significant differences $(\mathrm{p} \leq 0.01)$ between cultivars (Table 1). Ica Única cultivar $\left(2.73 \mathrm{~kg} \mathrm{plant}^{-1}\right)$ was the best compared to the other cultivars evaluated;

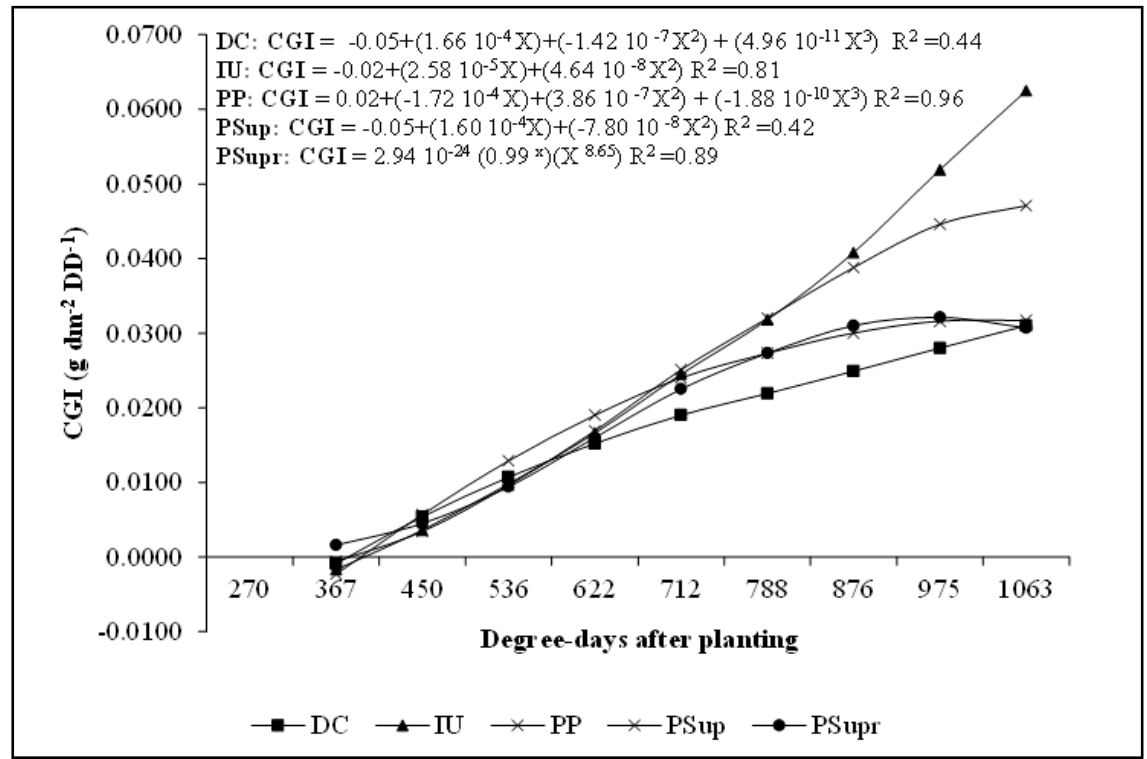

Figure 4. Progress crop growth index (CGI) curves through accumulated degree-days (DD) of Diacol Capiro (DC), Ica Única (IU), Parda Pastusa (PP), Pastusa Superior (PSup), and Pastusa Suprema (PSupr). Colombia, AGROSAVIA, 2018.

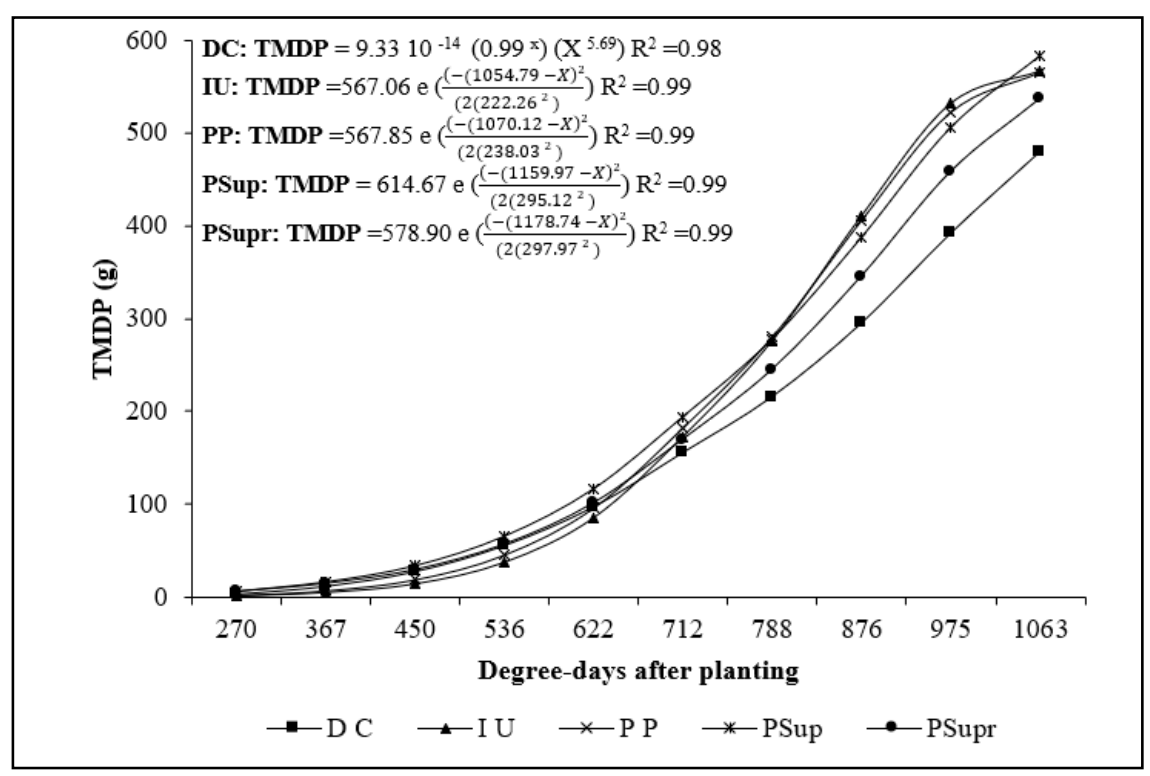

Figure 5. Progress total dry matter per plant (TDMP) curves through accumulated degreedays (DD) of Diacol Capiro (DC), Ica Única (IU), Parda Pastusa (PP), Pastusa Superior (PSup) and Pastusa Suprema (PSupr). Colombia, AGROSAVIA, 2018.

however, Pastusa Suprema, Pastusa Superior, Parda Pastusa and Diacol Capiro showed no statistical differences among them.

The results presented in this study exceed those reported by Jerez \& Martín (2012), who reported yields for Spunta of $1 \mathrm{~kg} \mathrm{plant}{ }^{-1}$, attributed mainly to limitations found in the field as well as cultivar and climatic factors which regulate transpiration, photosynthesis and respiration processes. Likewise, these results surpassed those obtained by Rodríguez et al. (2016), who reported a yield under greenhouse conditions for the cultivars Diacol Capiro, Esmeralda, and Suprema of 0.56, 0.42 and $0.28 \mathrm{~kg}$ plant $^{-1}$, respectively. In addition, under controlled conditions, Romero et al. (2017) in Cundinamarca, reported yields of $0.52 \mathrm{~kg}$ plant $^{-1}$ for Diacol Capiro and $0.53 \mathrm{~kg} \mathrm{plant}^{-1}$ for Perla Negra, differences that can be attributed to the growth of cultivars in non-optimal temperature and relative humidity conditions, as well as the utilization 
of previously used containers which affected the development of roots and stolon growth. In overall, the cultivars showed a good yield associated with the seeds tuber quality from the formal system and the integrated pest and diseases management, fertilization according to the soil analysis, and the required labor carried out on time. The high yields of Ica Única, Pastusa Superior, and Diacol Capiro coincided with high NAI values, confirming that higher photosynthetic efficiency is related to higher productivity.

Finally, yield of seed tubers expressed in percentage showed highly significant differences $(p \leq 0.01)$ for the seed tubers (Table 1); the highest percentages without significant differences among them were found in the cultivars Diacol Capiro, Pastusa Superior, Parda Pastusa and Pastusa Suprema. However, the percentage of Ica Unica was the lowest (Table 1). Consequently, all cultivars, except Ica Única, showed a high proportion of tubers suitable for seed, with values ranging from $80.82 \%$ to $87.40 \%$, which can be attributed to the genetic response of the cultivar and interaction with other factors under the experimental condition, such as soil preparation and cultural crop practices (CIP, 2011; López et al., 2014). The percentages of seed tubers observed in this study are within the ranges reported by Instituto de Investigaciones Agropecuarias (INIA, 2016) in Chile for the Patagonia-INIA cultivar, with values between $77 \%$, to $92 \%$ under various planting densities, showing that at a higher planting density, the production of seed tubers increased.

The growth models that showed a better adjustment to explain the response of the plant height, leaf area index, net assimilation index, crop growth index and total dry matter based on thermal accumulation in degree-days, corresponded mostly to models that show a smaller initial growth (Phase I), high increases in Phase II and stability at the end of the cycle (Phase III). Hoerl, Gaussian, and the third-degree polynomial models were the most representative in this study.

The most productive cultivar obtained from basic seed was Ica Única with $2.73 \mathrm{~kg}$ plant ${ }^{-1}$, but regarding the proportion of seed tubers produced, it showed the lowest percentage $(50.59 \%)$. Pastusa Suprema, Parda Pastusa, Pastusa Superior, and Diacol Capiro produced seed tubers in a higher percentage of total yield, with values ranging between $80.82 \%$ and $87.40 \%$. The growth response of the five cultivars through thermal accumulation was different and reflected both the yield and the production of basic seed tubers per plant with values higher than $80 \%$, except for Ica Única cultivar.

\section{ACKNOWLEDGMENTS}

The authors thank to the science, technology and innovation component of Sistema General de Regalias (SGR) and Governación de Nariño for funding this study, Corporación Colombiana de Investigación Agropecuaria (AGROSAVIA) and Universidad de Nariño (UDENAR) for supporting the experiments.

\section{REFERENCES}

AGUILAR, M; CARRILLO, J; RIVERA, A; GONZÁLEZ, V. 2006. Análisis de crecimiento y de relaciones fuente-demanda en dos variedades de papa (Solanum tuberosum L.). Revista Fitotecnia Mexicana 29: 145-156.

ARIZA, L. 2018. El sector de semillas en Colombia y sus desafíos. En: CONGRESO NACIONAL DE SEMILLAS. Resumenes... Bogotá D.C, Col: ACOSEMILLAS. (CDROM).

ASFAW, F. 2016. Effect of integrated soil amendment practices on growth and seed tuber yield of potato (Solanum tuberosum L.) at Jimma Arjo, Western Ethiopia. Journal of Natural Sciences Research 6: 38-63.

AWATI, R; BHATTACHARYA, A; CHAR, B. 2018. Rapid multiplication technique for production of high-quality seed potato (Solanum tuberosum L.) tubers. Journal Applied Biology \& Biotechnology 7: 1-5.

BUCKSETH, T; SHARMA, A; PANDEY, A; SINGH, B; MUTHURAJ, R. 2016. Methods of pre-basic seed potato production with special reference to aeroponics - A review. Scientia Horticulturae 204: 79-87.

CAMPOSTRINI, E; YAMANISHI, O. 2001. Estimativa da área foliar do mamoeiro utilizando o comprimento da nervadura central. Scientia Agrícola 58: 39-42.

CAO, W; TIBBITTS, T. 1995. Leaf emergence on potato stems in relation to thermal time. Agronomy Journal 87: 474-477.
CARDONA, C; ARAMÉNDIZ, H; BARRERA, C. 2009. Estimación del área foliar de papaya (Carica papaya L.) basada en muestreo no destructivo. Revista UDCA Actualidad \& Divulgación Científica 12: 131-139.

CENTRO INTERNACIONAL DE LA PAPA (CIP). 2011. Manejo del tubérculo semilla. https://cipotato.org/es/sin-categorizar/manejodel-tuberculo-semilla/. Accessed March 5, 2019.

DE LA CASA, A; OVANDO, G; BRESSANINI, L; MARTÍNEZ, J; RODRÍGUEZ, A. 2011. Eficiencia en el uso de la radiación en papa estimada a partir de la cobertura del follaje. Agriscientia 28: 21-30.

DE LA CASA, A; OVANDO, G; BRESSANINI, L; RODRÍGUEZ, Á; MARTÍNEZ, J. 2007. Uso del índice de área foliar y del porcentaje de cobertura del suelo para estimar la radiación interceptada en papa. Agricultura Técnica 67: 78-85.

FAGERIA, N; BALIGAR, V; CLARK, R. 2006. Physiology of crop production. New York: Haworth Press. p72.

FEDEPAPA. 2017. Contexto sectorial. https://fedepapa.com/wp-content/ uploads/2017/01/1.-PLANEACION.-FNFPD-PE-03-Plan-Estrategico.pdf. Accessed February 15, 2021.

HOWLADER, O; HOQUE, M. 2018. Growth analysis and yield performance of four potato (Solanum tuberosum L.) varieties. Bangladesh Journal of Agricultural Research 43: 267-280.

HUNT, R; CAUSTON, D; SHIPLEY, B; ASKEW, A. 2002. A modern tool for classical growth analysis. Annals of Botany 90: 485-488.

INSTITUTO COLOMBIANOAGROPECUARIO (ICA). 2015. Resolución $n^{\circ} 003168$ del 7 septiembre del 2015. https://www.ica.gov. co/getattachment/4e8c3698-8fcb-4e42-80e7a6c7acde9bf8/2015R3168.aspx. Accessed 17 November, 2020.

INSTITUTO DE INVESTIGACIONES AGROPECUARIAS (INIA). 2016. Manual Interactivo de la Papa INIA. Densidad de plantación para producción de consumo. http://manualinia.papachile. $\mathrm{cl} /$ ? page $=$ consumo\&ctn $=232$. Accessed February 21, 2018.

JEREZ, E; MARTÍN, R. 2012. Comportamiento del crecimiento y el rendimiento de la variedad de papa (Solanum tuberosum L.) Spunta. Cultivos Tropicales 33: 53-58.

JEREZ, E; MARTÍN, R; MORALES, D. 2016. Comportamiento de la acumulación y distribución de masa seca en tres variedades de papa (Solanum tuberosum L.). Cultivos Tropicales 36: 70-76.

LÓPEZ, A; GÓMEZ, M; RODRÍGUEZ, L. 2014. Effect of edaphic and foliar applications of different doses of zinc on the yield of the Criolla Colombia cultivar. Agronomía Colombiana 32: 70-77.

MADR. 2014. Diagnóstico de la cadena productiva de la papa. https://sioc.minagricultura.gov.co/ Papa. Accessed February 15, 2021.

MADR, 2019. Estrategias de ordenamiento de la producción cadena productiva de la papa y su Industria. https://sioc.minagricultura. gov.co/Papa/Normatividad/Plan $\% 20 \mathrm{de} \% 20$ 
Ordenamiento\%20papa\%202019-2023.pdf. Accessed February 12, 2021.

MILLER, P; LANIER, W; BRANDT, S. 2001. Using growing degree days to predict plant stages. Montana State University-Bozeman 59717: 994-2721.

PESKE, ST; BRAGA, LO; SOUZA, AC. 2010. Benefícios e obtenção de sementes de alta qualidade. https://seednews.com. br/artigos/1819-beneficios-e-obtencaode-sementes-de-alta-qualidade-edicaosetembro-2010. Accessed April 15, 2018.

PIEDRA, JA. 2016. Conceptos iniciales en la producción de semilla de papa. En: ANDRADE-PIEDRA, JL; KROMAN, P; OTAZÚ, V (eds). Manual para la producción de semilla de papa usando aeroponía: diez años de experiencias en Colombia, Ecuador y Perú. Centro Internacional de la papa (CIP), Instituto Nacional de Investigaciones
Agropecuarias (INIAP), Corporación Colombiana de Investigación Agropecuaria (Corpoica), Quito. p.270.

RODRÍGUEZ, L. 2010. Ecofisiología del cultivo de la papa (Solanum tuberosum L.). Revista Colombiana de Ciencias Hortícolas 4: 97-108.

RODRÍGUEZ, L; SANJUANELO, D; ÑÚSTEZ, C; MORENO, L. 2016. Growth and phenology of three Andean potato varieties (Solanum tuberosum L.) under water stress. Agronomia Colombiana 34: 141-154.

ROMERO, A; ALARCÓN, A; VALBUENA, R; GALEANO, C. 2017. Physiological assessment of water stress in potato using spectral information. Frontiers in Plant Science 8: 1608.

SAntos, M; SEGURA, M; ÑÚsteZ, C. 2010. Análisis de crecimiento y relación fuente-demanda de cuatro variedades de papa
(Solanum tuberosum L.) en el municipio de Zipaquirá (Cundinamarca, Colombia). Revista Facultad Nacional de Agronomía Medellín 63: 5253-5266.

SILVA, A; ALBORNOZ, C; CRIOLLO, H. 2018. Efecto del potasio y la densidad de siembra en la producción de papa Solanum tuberosum Grupo Phureja var. Criolla Guaneña. Temas Agrarios 23: 37-46.

THOMAS-SHARMA, S; ABDURAHMAN, A; ALI, S; ANDRADE-PIEDRA, JL; BAO, S; CHARKOWSKI, AO; CROOK, D. 2016. Seed degeneration in potato: the need for an integrated seed health strategy to mitigate the problem in developing countries. Plant Pathology 65: 3-16.

WARREN, J. 1981. Analysis of growth, photosynthesis and light interception for single plants and stands. Annals of Botany 48: $507-512$. 